\title{
Современные теоретические аспекты института международно-правовой защиты и поощрения прав ребенка
}

\section{Никонов Катажина*}

Международная защита прав человека является одной из важнейших отраслей современного международного права. Ее становление складывалось не просто. История защиты прав человека уходит далеко в прошлое. Первые нормы, регулирующие правовой статус индивида, присутствовали в национальных законодательствах Древнего Рима и Древней Греции, в Англии в период феодализма (Великая хартия вольностей 1215 года, Акт о лучшем обеспечении свободы подданного и о предупреждении заточений за морями 1679 года, Билль о правах 1689 года, Акт о дальнейшем ограничении Короны и лучшем обеспечении прав и вольностей подданного 1701 года), в США (Декларация независимости 1776 года, Конституция США 1787 года, Билль о правах 1789 года), во Франции в результате достижений Великой французской революции (Декларация прав человека и гражданина 1789 года)ㄹ․ Сама же концепция прав человека и основных свобод как категории появилась в XVII веке в Европе. Она была сформулирована в трудах таких известных мыслителей, как Гуго Гроций, Джон Локк, Эдмунд Бурк, в XVIII же веке, получила свое развитие в трудах Томаса Пейна. Первоначально данная концепция формировалась как одна из философских категорий, плод развития гуманитарной мысли. Дальнейшее развитие и оформление прав человека как государственной, социальной категории происходило постепенно, по мере признания отдельными государствами в качестве одного из направлений их деятельности ${ }^{2}$.

Приведенные выше примеры государственных актов, имели непосредственное отношение только к своим гражданам. До окончания Второй мировой войны права человека и их защита фактически входили исключительно во внутреннюю компетенцию государств. Единс-

\footnotetext{
* Никонов Катажина - аспирант кафедры международного права МГИМО (У) МИД России.

1 Международное право / Отв.ред. Ю.М. Колосов, Э.С. Кривчикова. М., 2005. C. 532 .

2 Łopatka A. Międzynarodowe prawo praw człowieka. Zarys. Warszawa, 1998. Str.10.
} 
твенной попыткой интернационализации данного вопроса была Лига Наций (1920 г.). Одной из ее основных задач, помимо предупреждения повторного наступления войны, было предупреждение нарушения прав человека, что было подтверждено Женевской Декларацией 1924 года ${ }^{3}$.

Современный этап развития прав человека начинается с момента образования Организации Объединенных Наций (1945 г.). Статья 1 Устава ООН устанавливает в качестве одной из целей Организации осуществление международного сотрудничества в разрешении международных проблем экономического, социального, культурного и гуманитарного характера и в поощрении и развитии уважения к правам человека и основным свободам для всех, без различия расы, пола, языка и религии.

10 декабря 1948 года Генеральной Ассамблеей ООН была принята Всеобщая декларация прав и свобод человека и гражданина, в преамбуле к которой говорится, что признание человеческого достоинства, равных и неотъемлемых прав является основой свободы, справедливости и всеобщего мира. В дальнейшем принятие в 1966 году Международного пакта об экономических, социальных и культурных правах и Международного пакта о гражданских и политических правах, а впоследствии и других универсальных и региональных актов в области прав человека, о которых более подробно речь пойдет далее, закрепило принцип уважения прав человека, ставший одним из основных принципов международного права.

В ходе дальнейшего развития прав человека произошло выделение в данной отрасли права отдельных институтов, одним из которых в современном международном праве является институт международно-правовой защиты прав ребенка. Развитие и становление данного аспекта прав человека в качестве самостоятельного правового института имеет достаточно длинную историю. Ребенок не рассматривался как представитель отдельной социальной категории достаточно долгое время. В правовом смысле ребенок не существовал вовсе, а в отдельных государствах, где в законодательных актах шла речь о ребенке, он воспринимался как собственность своего отца, и отношение к нему было таким же, как к другой собственности. Высокая детская смертность была также причиной того, что до возраста 6-7 лет основной задачей

${ }^{3}$ Understanding Children's Rights / Edited by Eugeen Verhellen. Children's Rights Centre, University of Ghent, Belgium, 1998. P. 25. 
ребенка было выжить, после чего он терялся в мире взрослых и обязанности его практически ничем не отличались от обязанностей взрослого гражданина. В дальнейшем, уже в XVIII веке, в эпоху Просвещения, дети стали рассматриваться как отдельная социальная группа. Но и тут делался акцент на восприятие ребенка как будущего человека, как «творца будущего»; ребенок стал «благополучием завтрашнего дня». Такой акцент на будущее сделал ребенка «еще не человеком», так как ребенок «многого еще не может», «еще не понимает», «еще не умеет». Именно в таком качестве «еще не человека» ребенок стал восприниматься как отдельная социальная группа. Для реализации этих идей был создан ряд правовых механизмов и институтов. В начале XX века в ряде западных стран появились законы о защите детей и об обязательном образовании. Ребенок перестал восприниматься как собственность родителей и стал частью государства, а его задачей было готовиться к настоящей, взрослой жизни. Данное восприятие ребенка как категории макросоциальной нашло свое отражение и в уже упомянутой Женевской декларации 1924 года, и, в несколько меньшей степени, в Декларации прав ребенка 1959 года. Эти документы трактуют ребенка не как субъект прав, а скорее как их объект, что подтверждается самой терминологией данных документов: «Ребенку следует гарантировать», «Ребенку необходимо предоставить...», и т.д.

В течение последних десятилетий ситуация, безусловно, изменилась. Стоит отметить, что уже Всеобщая декларация прав человека (1948 г.) не дифференцирует права в зависимости от возраста человека: «Все люди рождаются свободными и равными в своем достоинстве и правах» ${ }^{4}$ (ст. 1). Ребенок является полноценным членом современного общества, и необходимо трактовать его в качестве полноправного субъекта социальной жизни. Именно он сам, как субъект этих отношений, является носителем всех тех прав и свобод, которые являются общепризнанными правами человека 5 .

Международно-правовая защита прав ребенка является частью отдельной отрасли международного права - международной защиты прав человека. В соответствии с общей теорией права система права делится на несколько фундаментальных структурных элементов, вы-

4 Действующее международное право (избранные документы) / Отв.ред. Ю.М. Колосов, Э.С. Кривчикова. М., 2002. С. 776.

5 Understanding Children's Rights / Edited by Eugeen Verhellen. Children's Rights Centre, University of Ghent, Belgium, 1998. P. 22-23. 
деляемых в зависимости от объема и характера регулируемых отношений. Такими основными элементами системы права являются отрасль права и правовые институты. При этом под правовым институтом принято понимать обособленный комплекс правовых норм, являющихся специфической частью отрасли права и регулирующих разновидность определенного вида общественных отношений. Отрасль права, в свою очередь, являясь понятием более общим и всеобъемлющим, представляет собой относительно самостоятельное подразделение системы права, состоящее из правовых норм, регулирующих качественно специфический вид правовых отношений. Исходя из этого, многие теоретики международного права разрабатывали понятие института и отрасли права применительно к международному праву, принимая во внимание специфику международного права и его субъектов. Например, в учебнике под ред. Ю.М. Колосова и Э.С. Кривчиковой по международному праву отрасль международного права определяется как «совокупность юридических норм, регулирующих отношения субъектов международного права в определенной области, которая составляет специфический предмет международного права, обладает большой степенью универсальной кодификации и характеризуется наличием принципов, применимых к данной конкретной области правоотношений»; международно-правовой институт - как «группа норм и принципов, регулирующих определенную область правоотношений» 6 .

Хотя в современном международном праве нет однозначного перечня существующих и общепринятых отраслей международного права и на этот счет существует множество различных мнений, международная защита прав человека является самостоятельной отраслью международного права в соответствии со всеми имеющимися на сегодняшний день классификациями. В отношении данной отрасли вопрос различий в подходах теоретиков связан лишь с названием самой отрасли. Она называется «Международное гуманитарное право» (Г.В. Игнатенко, О.И. Тиунов); «Международная защита прав человека» (Ю.А. Решетов, В.А. Карташкин); «Права человека в международном праве» (С.В. Черниченко); «Международное право прав человека» (Е.Г. Моисеев); «Личность в международном праве» (Г.Г. Шинкарецкая) и т.д. ${ }^{7}$. Однако, наполнение данных названий остается одинаковым.

6 Международное право / Отв.ред. Ю.М. Колосов, Э.С. Кривчикова. М., 2005. С. 27.

7 Международное публичное право / Отв.ред. К.А. Бекяшев. М., 2005. С. 227. 
Отрасль, которую мы будем называть «Международно-правовая защита прав человека», сложилась как особая отрасль международного права, которой свойственны некоторые особенности. Во-первых, в отношении прав человека все чаще встречается мнение о том, что существует ряд основополагающих обязательств для всего мирового сообщества, не зависящих от того, выразило ли конкретное государство свое формальное согласие на соблюдение определенных норм или нет. Здесь, несомненно, под вопрос ставится положение Венской конвенции о праве международных договоров, гласящее, что договор не создает прав и обязательств для третьего государства без его на то согласия (ст. 34). Кроме того, в данной отрасли ограничено применение института оговорок к международным договорам, как это было в отношении Конвенции о предупреждении преступлений геноцида и наказании за него, в отношении которой Международным судом ОOH было принято консультативное заключение о том, что в связи с гуманитарной общечеловеческой ценностью положений договора государство не может отказаться от соответствующих обязательств, мотивируя отказ оговоркой. И наконец, обязательства по соблюдению принципов и норм, касающихся основных прав человека, не носят характера взаимности, являясь обязательствами по отношению к мировому сообществу в целом. И любая международная организация или любое государство может потребовать соблюдения этих обязательств в случае грубого их нарушения.

Указанные особенности отрасли международно-правовой защиты прав человека подчеркивают необыкновенную важность для современного мира соблюдения этих прав и критичность обеспечения их защиты. Международно-правовая защита прав ребенка занимает в данной отрасли международного права особое место. С момента провозглашения в 1924 году Лигой Наций Женевской декларации в международном праве появился новый аспект защиты прав человека - защита прав ребенка. Выделению данного аспекта международно-правовой защиты прав человека в отдельный сегмент отрасли способствовало дальнейшее провозглашение в рамках $\mathrm{OOH}$ Декларации прав ребенка 1959 года и принятие Генеральной Ассамблеей ООН в 1989 году Конвенции ООН о правах ребенка, ратифицированной в 1990 году. Выделение ребенка из общей категории «человек» неслучайно. Международно-правовая защита прав ребенка обладает рядом особенностей, которые определяют специфику данного аспекта. 
На наш взгляд, данная специфика вполне соответствует понятию и рамкам отдельного института международного права. Итак, вернемся к теории международного права, согласно которой международно-правовой институт - это группа норм и принципов, регулирующих определенную область правоотношений соответствующей отрасли международного права. Особенности правового статуса ребенка как отдельной категории в рамках международно-правовой защиты прав человека касаются как самого субъекта прав, коим является ребенок, так и круга подлежащих защите прав, носителем которых он является. Национальные законодательства большинства государств выделяют ребенка в отдельную социальную группу населения. До определенного возраста ребенок требует особого внимания и особой защиты. Он более чем кто бы то ни было подвержен воздействию окружающего мира, так как не в состоянии в силу объективных причин самостоятельно обеспечить свою безопасность и благополучие. Однако, как уже упоминалось выше, у выделения ребенка в отдельную правовую категорию, то есть у особого правового статуса ребенка, есть и другая сторона. В современном правосознании существует понятие несамостоятельности ребенка как субъекта права. Мировое сообщество, с одной стороны, признает, что ребенок, будучи человеком, должен иметь возможность пользоваться всеми присущими человеку правами. С другой стороны, не всеми правами человека ребенок в состоянии пользоваться в силу того, что он не может самостоятельно принимать определенные решения и осознавать их последствия. Необходимость и целесообразность рассмотрения международно-правовой защиты прав ребенка как отдельного международно-правового института не имели бы смысла в том случае, если бы можно было поставить знак равенства между двумя понятиями - «ребенок» и «человек» - в смысле их правового статуса, под которым мы понимаем определенный существующий набор прав и обязанностей. Однако «компетентность» ребенка как полноправного человека ставится под сомнение, порождая некий дуализм в подходе к ребенку как носителю прав человека. Текст Конвенции о правах ребенка только подтверждает данное утверждение, не закрепляя правового статуса ребенка как обладателя общепризнанных прав человека, ограничиваясь наделением ребенка некоторыми основными правами человека (ст. 12-16 Конвенции) ${ }^{8}$. Кроме того, в Конвенции подчерки-

${ }^{8}$ Understanding Children's Rights / Edited by Eugeen Verhellen. Children's Rights Centre, University of Ghent, Belgium. 1998. P. 36-37. 
вается причина такого отношения к ребенку, в некотором смысле ограничивающая его в правах. Ребенок, являясь уязвимым существом «ввиду его физической и умственной незрелости, нуждается в специальной охране и заботе, включая надлежащую правовую защиту» (п. 9 Преамбулы). Таким образом, «дети имеют право на особую заботу и помощь» (п. 4 Преамбулы $)^{9}$.

В некоторых исследованиях по правам ребенка в международном праве прослеживается мысль о том, что международное сообщество должно стремиться к уменьшению различий между правовым содержанием категорий «человек» и «ребенок» в аспекте прав, которыми они наделяются ${ }^{10}$. Однако, на наш взгляд, такое уравнивание не только невозможно, но и нецелесообразно, так как в определенном смысле противоречит самому правовому статусу ребенка как особой категории населения. Признание того, что ребенок должен пользоваться в полной мере всеми теми правами, которые принято называть основными правами человека, и того, что ему необходимо предоставить ряд особых прав, а все присущие ребенку права должны подлежать особой защите, является целью мирового сообщества и международного права в данном аспекте. Стоит также обратить внимание на существование другого мнения, которое выражают заявления некоторых государств о том, что нет необходимости в существовании отдельного института международной защиты прав ребенка. Это утверждение основано на том, что ребенок пользуется всеми правами наравне со взрослыми и, поскольку в конституциях и законах многих государств говорится о равенстве всех людей в их правах, нет смысла уделять особого внимания правам ребенка, так как они ничем не отличаются от прав взрослого человека, т.е. от общего понимания прав человека. Однако данное утверждение мы будем также считать необоснованным и в связи с ним приведем аргументацию, предложенную Ю.М. Колосовым. Вопервых, в большинстве обществ дети не воспринимаются как полноценные граждане, так как они не полностью дееспособны. Каждое государство устанавливает различные возрастные границы для определенных действий, составляющих объем частичной дееспособности

9 Права человека в международном и внутригосударственном праве / Отв.ред Р.М. Валеев. Казань, 2004. С. 146.

${ }^{10}$ Verhellen E. The Convention on the Rights of the Child // Understanding Children's Rights / Edited by Eugeen Verhellen. Children's Rights Centre, University of Ghent. Belgium, 1998. P. 21-38. 
ребенка, как то, например, медицинские консультации без присутствия родителей, минимальный возраст для вступления в брак, трудоустройства и др. Соответственно, между ребенком и взрослым существуют вполне обоснованные, объективные различия, из которых следует, что все иные гражданские или другого рода права человека не воспринимаются уже как права, присущие ребенку на таких же основаниях, как и взрослому человеку. Именно поэтому права ребенка требуют отдельной регламентации.

Во-вторых, не любое право человека, закрепленное международноправовым документом, может относиться к ребенку. Для осуществления некоторых прав необходимо достижение совершеннолетия. К ним относятся в числе прочих: равенство всех перед законом (ребенок в определенном возрасте не несет уголовной ответственности), свобода передвижения и выбора места жительства, право на вступление в брак и создание семьи безо всяких ограничений, право на участие в управлении государством и на участие в выборах, право на добровольное вступление в ряды вооруженных сил и многие другие права. Некоторые права могут осуществляться ребенком только через его законных представителей: это право быть зарегистрированным сразу после рождения, право на имя, право собственности и др. Таким образом, становится очевидным, что особая регламентация прав ребенка необходима. Люди в возрасте до 18 лет составляют около пятидесяти процентов населения Земли. В большинстве случаев они не могут осуществлять свои права самостоятельно, тем более обеспечить их защиту. Решения за ребенка принимают родители или опекуны, от них же зависит благополучие ребенка. Есть и еще более уязвимые дети, оказавшиеся в ситуации вооруженного конфликта, дети-беженцы, дети трудящихся-мигрантов, дети без гражданства, дети-инвалиды, и т.д. Они нуждаются в специальной защите, еще более организованной и направленной на соблюдение их прав и интересов ${ }^{11}$.

Таким образом, в современном международном праве существует и будет существовать определенная разница в понятиях «защита прав человека» и «защита прав ребенка». Данные категории никогда не должны полностью отождествляться, так как ребенок всегда будет нуждаться в особой защите. Ребенок - это, бесспорно, человек и,

${ }^{11}$ Kolosov Y. The CRC: Juridical significance and the Committee on the Rights of the Child: Stock taking and new challenges // Understanding Children's Rights / Edited by Eugeen Verhellen. Children's Rights Centre, University of Ghent. Belgium, 1998. P. 397-398, 395. 
как любой другой человек, должен пользоваться теми правами, которые ему присущи. Однако эти права будут и должны трактоваться несколько по-иному, чем права человека в целом. И именно особенность прав ребенка, порожденная спецификой его правосубъектности, создает основу для того, чтобы международно-правовую защиту прав ребенка выделять и определять в качестве особого международно-правового института.

Здесь возникает еще один момент, на котором можно основываться при определении международно-правовой защиты прав ребенка как отдельного института международного права, а именно отдельная система источников, регулирующих данный институт. Далее мы предложим классификацию источников международного права, образующих и регулирующих международно-правовую защиту прав ребенка как международно-правовой институт.

Поскольку закрепление принципа уважения прав человека в качестве одного из основных принципов международного права явилось, на наш взгляд, основой и предпосылкой для формирования соответствующей отрасли международного права, следует сказать о нем более подробно. Самостоятельно принцип уважения прав человека был закреплен лишь в Заключительном акте СБСЕ 1975 года. Однако, учитывая, что Устав ООН содержит юридически обязательные общие положения о необходимости осуществления международного сотрудничества в поощрении и развитии уважения к правам и основным свободам человека, а также указание на основополагающее значение достоинства и ценности человеческой личности, равноправие народов, равноправие мужчины и женщины, недопустимость дискриминации по признаку пола, расы, языка и религии, можно говорить о более раннем становлении данного принципа. Утверждение принципа уважения прав человека в международном праве внесло изменения в саму концепцию этого права. Если ранее международное право было полностью изолировано от того, что происходило внутри государств, то теперь на государства стало налагаться обязательство уважать права находящихся на их территории людей. Отношение государств к своему населению стало объектом внимания международного сообщества. Государства взяли на себя обязательство соблюдать исторически достигнутые стандарты прав человека, поскольку, в частности, от этого зависят и межгосударственные отношения. Кроме того, права человека в современном мире превалируют над правами государства, народа 
и их частей. Согласно международному праву, ни государство, ни какая-либо группа или какое-либо лицо не имеют права заниматься какой бы то ни было деятельностью, направленной на уничтожение или неправомерное ограничение любых международно признанных прав человека ${ }^{12}$. Эта обязанность носит всеобщий характер. Это значит, что права и свободы человека должны соблюдаться во всех государствах и действовать в отношении всех лиц, находящихся под юрисдикцией государства, без какой-либо дискриминации, а международное право устанавливает в этом отношении минимальные стандарты ${ }^{13}$.

Таким образом, мы исходим из того, что принцип уважения прав человека является одним из основных принципов международного права и на нем основываются все без исключения источники современного международного права, как имеющие непосредственное отношение к отрасли защиты прав человека, так и все иные.

Как известно, наиболее распространенным и значимым на сегодняшний день источником международного права являются многосторонние международные договоры. Среди них целесообразно выделить в первую очередь универсальные международные договоры, то есть договоры с неограниченным количеством участников. Принимая во внимание тот факт, что в сфере международно-правовой защиты прав ребенка огромное значение имеют акты общего характера, предоставляющие защиту прав человека в целом, начнем с них. Несмотря на то что подобные международно-правовые соглашения практически не предоставляют особую защиту ребенку как представителю отдельной социальной группы, все же их положения имеют значение и для защиты прав ребенка. Среди них следует выделить Международные пакты 1966 года об экономических, социальных и культурных правах, а также о гражданских и политических правах. В частности, Пакт об экономических, социальных и культурных правах гарантирует проведение государствами мероприятий по обеспечению сокращения мертворождаемости и детской смертности и здорового развития ребенка; обеспечению бесплатного обязательного начального образования; обеспечению особых мер охраны и помощи в отношении всех

12 Статья 5, п. 1: Международный пакт о гражданских и политических правах 1966 года // Действующее международное право (избранные документы) / Отв.ред. Ю.М. Колосов, Э.С. Кривчикова. Москва, 2002. С. 788.

13 См.: Международное право/ Отв.ред. Ю.М. Колосов, Э.С. Кривчикова. Москва, 2005. С. 92-93.; Лукашук И.И. Международное право. Общая часть. Москва, 1997. C. 259-264. 
детей и подростков, в том числе мер по их защите от экономической и социальной эксплуатации, а также применению внутри государства санкций за использование детского и подросткового труда в области, вредной для их нравственности и здоровья и опасной для жизни. Пакт о гражданских и политических правах предусматривает запрет на вынесение смертного приговора в отношении лиц моложе восемнадцати лет, возможность исключения из общего правила публичного рассмотрения уголовных и гражданских дел в суде, если интересы несовершеннолетних детей требуют другого или когда дело касается опеки над детьми; кроме того, положения данного Пакта предусматривают, что в отношении несовершеннолетних процесс должен быть таков, чтобы учитывались их возраст и желательность содействия их перевоспитанию ${ }^{14}$.

К международно-правовым актам универсального характера, гарантирующим защиту прав человека в общем, и ребенка в частности, относятся и все другие международно-правовые договоры о правах человека, как то: Конвенция против пыток и других жестоких, бесчеловечных или уничижающих достоинство видов обращения и наказания 1984 года, Международная конвенция о ликвидации всех форм расовой дискриминации 1965 года, а также Конвенция о ликвидации всех форм дискриминации в отношении женщин 1979 года, в особенности в той части, где речь идет о равных правах на получение образования, в том числе дошкольного и общего школьного образования ${ }^{15}$.

Наряду с универсальными международными договорами следует отметить значение международных договоров регионального характера, гарантирующих защиту прав человека в целом. Среди них можно выделить договоры, заключенные в рамках Организации по безопасности и сотрудничеству в Европе, Совета Европы, Европейского союза и СНГ. Более подробно об учреждаемых этими договорами механизмах защиты прав ребенка речь пойдет далее, здесь же мы приведем лишь некоторые примеры соответствующих документов и предоставленных ими гарантий.

14 Международный пакт об экономических, социальных и культурных правах 1966 г. // Действующее международное право (избранные документы) / Отв. ред. Ю.М. Колосов, Э.С. Кривчикова. М., 2002. С. 780-787; Международный пакт о гражданских и политических правах 1966 г. // Там же. С. 787-800.

15 Текст документов см.: Основные международные договоры по правам человека. Управление Верховного Комиссара ООН по правам человека. ООН. Нью-Йорк и Женева, 2006. 
Огромное значение для защиты прав человека имеет подписанная в рамках Совета Европы в 1950 году Европейская конвенция о защите прав человека и основных свобод, а также обе Европейские социальные хартии - 1961 года и Пересмотренная европейская социальная хартия 1996 года. В рамках ОБСЕ речь идет, безусловно, об упомянутом уже не раз Заключительном акте СБСЕ 1975 года, закрепляющем существование самостоятельного принципа международного права - принципа уважения прав человека, а также об Итоговом документе Венской встречи СБСЕ 1989 года, который уделил особое внимание решению проблем воссоединения несовершеннолетних детей с их родственниками, упрощая для них процедуры пересечения государственных границ, наложив при этом на государства - участников организации обязательство следовать при рассмотрении ходатайств о поездках за границу принципу недискриминации, в том числе по признаку возраста ${ }^{16}$. Говоря о договорах Европейского союза, следует отметить подписание Амстердамского договора 1997 года, одной из основных целей которого было названо сосредоточение усилий Евросоюза на проблемах занятости и прав человека. При этом в данном договоре речь идет, в частности, о средствах борьбы с дискриминацией по возрастному признаку. Среди договоров, предоставляющих защиту прав человека в общем смысле, в рамках СНГ следует отметить Конвенцию о правах и основных свободах человека 1995 года, закрепившую, наряду с основными правами человека и гражданскими правами, право на охрану здоровья, социальное обеспечение со стороны государства и др. ${ }^{17}$.

Следующую ступень в нашей классификации источников международного права, регулирующих институт защиты прав ребенка, образуют международные договоры, имеющие непосредственное отношение к детям. Их мы также будем подразделять на договоры универсального и регионального характера.

Центральное место здесь, безусловно, занимает Конвенция ООН по правам ребенка 1989 года. Данная Конвенция является наиболее распространенным и широко признанным международно-правовым

16 Бобылев Г.В. Сотрудничество в гуманитарной области в рамках ОБСЕ // Европейское международное право / Отв. ред. Ю.М. Колосов, Э.С. Кривчикова, П.В. Саваськов. М., 2005. С. 327-330.

17 Иванов Д.В. Сотрудничество стран СНГ по защите прав человека // Европейское международное право / Отв. ред. Ю.М. Колосов, Э.С. Кривчикова, П.В. Саваськов. M., 2005. C. 347-350. 
актом по правам человека. Ее ратифицировали и присоединились к ней 192 государства. Сорок две статьи Конвенции закрепляют гражданские, политические, экономические, социальные и культурные права, призванные удовлетворять особым нуждам ребенка, которым в соответствии со ст. 1 Конвенции является «каждое человеческое существо до достижения 18-летнего возраста, если по закону, применимому к данному ребенку, он не достигает совершеннолетия ранее».

Конвенция ООН о правах ребенка охватывает широкую гамму прав. В ней нет четкого деления прав ребенка по обычным группам - на политические, экономические и культурные. Характерным для Конвенции является объединение всех прав по трем признакам в группы прав, предоставляющих ребенку обеспечение, защиту и участие. Таким образом, к первой группе прав относятся среди прочих: право на имя, гражданство, медицинскую и санитарную помощь, право на образование. К группе прав на защиту - права на защиту от определенных действий, например пыток, произвольного лишения свободы, вовлечения в качестве участников в вооруженные конфликты, необоснованного лишения семейной заботы, эксплуатации. Третью группу прав - на участие - образуют права на участие детей в принятии решений, касающихся их жизни, права на участие в жизни общества. Кроме того, анализируя положения Конвенции, стоит подчеркнуть, что предоставляемые ею права не гарантируют ребенку полную независимость и самостоятельность. Все обязательства государств, которые они взяли на себя в отношении ребенка, ратифицировав данную Конвенцию, можно подразделить на прямые, как, например, предоставление возможности для образования или обеспечение должного отправления правосудия в отношении несовершеннолетних, и косвенные, гарантирующие права родителей, опекунов ребенка играть свою основную роль и принимать участие в его жизни, выполняя свои обязанности в качестве воспитателей и защитников. Конвенция 1989 года, объединив разнообразные права ребенка в тексте одного документа, преследует три основные цели: 1) вновь подтвердить в отношении детей права, которые уже предоставлены людям вообще в рамках других договоров по правам человека в целом; 2) закрепить некоторые права человека, предоставляя в связи с особым статусом ребенка особые гарантии их защиты (условия труда, лишения свободы); 3)закрепить специальные нормы, касающиеся защиты тех прав, которые относятся непосредственно к ребенку, как то: вопросы усыновления/удочерения, доступ к начальному 
образованию, защита от насилия и отсутствия должной заботы в семье, а также вопросы о взыскании алиментов ${ }^{18}$. Кроме всего вышесказанного, Конвенция ввела две концепции, имеющие огромное значение для дальнейшего развития прав ребенка. Это концепция «наилучшего обеспечения интересов ребенка», которая становится обязательным критерием для «всех действий в отношении детей» ${ }^{19}$, а также принцип, в соответствии с которым лица, ответственные за ребенка (будь то родители или опекуны), должны «в соответствии с развивающимися способностями ребенка должным образом управлять и руководить им в осуществлении им признанных настоящей Конвенцией прав» ${ }^{20}$.

Другим достижением Конвенции стало учреждение контрольного органа за выполнением государствами взятых на себя обязательств, а именно Комитета ООН по правам ребенка, деятельность которого имеет для развития международно-правовой защиты прав ребенка определяющее значение.

Среди международных договоров регионального характера, предоставляющих гарантии прав ребенка, особого внимания заслуживает принятая в 1990 году в рамках Организации Африканского Единства Африканская хартия о правах и благополучии ребенка, вступившая в силу в 1999 году. Данный документ содержит все основные права и свободы ребенка, подразделяя их на общие и специальные, то есть такие права, которые присущи отдельным категориям детей. Кроме того, Африканская хартия содержит статьи об обязанностях родителей по отношению к детям (ст. 20), а также об ответственности ребенка (ст. 31). При этом одним из важнейших достижений в рамках данного документа является безоговорочное определение ребенка как человека в возрасте до 18 лет (ст. 2) 21.

Далее в нашей классификации международно-правовых источников защиты прав ребенка мы отметим международно-правовые акты,

18 Права ребенка. Конвенция о правах ребенка // Документы и материалы по правам человека / Права ребенка // Международное общественное объединение по научноисследовательским и информационно-образовательным программам «Развитие». http://evolutio.info

19 Статья 3, п.1 Конвенции ООН о правах ребенка 1989 г. //Основные международные договоры по правам человека. Управление Верховного Комиссара ООН по правам человека. ООН. Нью-Йорк и Женева, 2006. С. 108.

20 Статья 5 Конвенции ООН о правах ребенка 1989 г. // Там же. С. 108.

21 African Charter on the Rights and Welfare of the Child, OAU Doc. CAB/LEG/24.9/49 (1990) // University of Minnesota. Human Rights Library. 
предоставляющие специальную защиту прав ребенка. Среди них есть как документы, гарантирующие права ребенка как части человечества, уделяющие лишь в отдельных положениях особое внимание ребенку, так и документы, имеющие непосредственное отношение к правам ребенка. В связи с тем, что все они предоставляют гарантии защиты специальных прав ребенка, мы не будем их делить по данному признаку, так как чрезмерное дробление классификации источников может вызвать лишь необоснованную путаницу. Именно поэтому мы объединили данные источники в одну категорию нашей классификации лишь по признаку характеристики прав, которые они гарантируют.

К международно-правовым источникам универсального характера, предоставляющим особую защиту прав ребенка, следует отнести Женевские конвенции 1949 года и Дополнительные протоколы к ним 1977 года. Особое внимание непосредственной защите прав ребенка уделяет IV Женевская конвенция о защите гражданского населения во время войны 1949 года, содержащая ряд статей, имеющих отношение исключительно к детям. В данной сфере большое значение имеет также Второй дополнительный протокол 1977 года, касающийся защиты жертв вооруженных конфликтов немеждународного характера, так как в последнее время количество таких конфликтов сильно возросло и именно они характеризуются наибольшим количеством жертв среди гражданского населения, в особенности среди детей.

Среди иных актов, предоставляющих особую защиту ребенку, следует отметить Конвенцию о статусе беженцев 1951 года, а также Протокол 1967 года, касающийся статуса беженцев, который отменил ограничение действия Конвенции во времени ${ }^{22}$, вследствие чего она стала носить универсальный характер ${ }^{23}$.

К этой же группе источников относится Международная конвенция о защите прав всех трудящихся-мигрантов и членов их семей 1990 года, которая в своем тексте опирается на выработанные МОТ стандарты и принципы в области защиты прав соответствующей части населения ${ }^{24}$. Данная Конвенция предоставляет общую защиту прав

22 Конвенция о статусе беженцев 1951 г. распространяла свое действие до принятия Протокола 1967 г. лишь на лиц, которые стали беженцами до 1 января 1951 г.

23 Иванов Д.В. Беженцы в современном международном праве / Д.В. Иванов. М., 2006. С. 34-35.

24 В Преамбуле Конвенции 1990 г. содержатся прямые ссылки на тексты документов MOT: Конвенцию о трудящихся-мигрантах (№ 97), Конвенцию о злоупотреблении в области миграции и об обеспечении всем трудящимся-мигрантам равенства 
всех трудящихся- мигрантов в своей части третьей: «Права человека всех трудящихся- мигрантов и членов их семей», а также различный набор прав для трудящихся-мигрантов и членов их семей в зависимости от правового статуса конкретного лица в государстве его местонахождения в качестве трудящегося-мигранта. Различные виды правового статуса - это, согласно тексту Конвенции, «трудящиеся-мигранты и члены их семей, имеющие документы или постоянный статус» (часть четвертая Конвенции) и «конкретные категории трудящихся-мигрантов» (часть пятая Конвенции), к которым относятся: «приграничные трудящиеся», «сезонные трудящиеся», «работающие на проекте», «трудящиеся, работа которых связана с переездами», «трудящиесямигранты, работающие не по найму» и т.д.

Международно-правовым актом, принятым на уровне международной организации, значение которого также сложно переоценить, является Конвенция МОТ № 182 о запрещении и немедленных меpax по искоренению наихудших форм детского труда 1999 года. Данная конвенция обязывает государства предпринять незамедлительные и эффективные меры для того, чтобы обеспечить запрет и ликвидацию наихудших форм детского труда. Конвенция также запрещает работу, которая по своей природе или в силу условий, в которых она производится, способна нанести ущерб здоровью, безопасности или нравственности детей, однако оставляет государствам возможность самим определить, после консультаций с профсоюзами и нанимателями, какая работа должна подпадать под такой запрет. При этом понятие «ребенок» относится ко всем лицам до 18 лет. Вместе с тем в Конвенции предусмотрено, что в любом случае государства должны распространить ее на любое участие детей в военных действиях и военный призыв лиц, не достигших 18 лет.

В рамках ЮНЕСКО в 1960 году была принята Конвенция о борьбе с дискриминацией в области образования, гарантирующая отсутствие любых форм дискриминации в сфере образования. Конвенция предусматривает также обязательное общее начальное образование, которое должно быть бесплатным, доступность среднего образования

возможностей и обращения (№ 143), Конвенцию о принудительном или обязательном труде (№ 29) и Конвенцию об упразднении принудительного труда (№ 105), а также на ряд рекомендаций МОТ. Текст Конвенции 1990 г. см.: Основные международные договоры по правам человека. Управление Верховного Комиссара ООН по правам человека. ООН. Нью-Йорк и Женева, 2006. 
(ст. 4 Конвенции). Кроме этого, в Конвенции говорится о том, что образование должно быть направлено на всеобъемлющее развитие личности и укрепление возрастающего уважения к правам человека и основным свободам. Образование должно укреплять толерантность и дружбу среди всех национальных, расовых и религиозных групп и т.д. (ст. 5 Конвенции) 25.

Отдельную категорию в нашей классификации составят многочисленные акты, которые мы относим к разряду актов «мягкого» права, т.е. акты ненормативного содержания, носящие рекомендательный характер, но вместе с тем имеющие большое значение для института международно-правовой защиты прав ребенка. Среди актов «мягкого» права внимания заслуживают прежде всего акты, принятые $\mathrm{OOH}$ по правам ребенка, включая резолюции и доклады Генеральной Ассамблеи, доклады Генерального Секретаря ООН, доклады Экономического и социального совета, резолюции Совета Безопасности. Мы отметим те из них, которые имеют наибольшее значение для развития института защиты прав ребенка.

Безусловно, наиболее известной и обсуждаемой является Резолюция ГА от 26 июня 2000 года. Она приурочена к десятой годовщине встречи на высшем уровне в интересах детей и вступления в силу Конвенции о правах ребенка. В резолюцию включены тексты двух факультативных протоколов к Конвенции о правах ребенка от 25 мая 2000 года: касающегося участия детей в вооруженных конфликтах и касающегося торговли детьми, детской проституции и детской порнографии. Данные протоколы содержат ряд положений, предоставляющих особую защиту детям, столкнувшимся или затронутым соответствующими обстоятельствами. К сожалению, ни один из них не вступил пока в силу, однако их значение для защиты прав ребенка достаточно велико, так как многие международные организации, занимающиеся защитой прав ребенка, в своей деятельности опираются на положения этих Протоколов и часто ссылаются на них в принимаемых внутри организаций актах. Кроме данной Резолюции, можно отметить целый ряд подобных актов органов ООН, например Резолюцию 51/77 от 12 декабря 1996 года, которая учредила должность Специального представителя Генерального Секретаря по вопросам детей в вооруженных конфликтах. Данная должность была учреждена с целью улучшения согласованности действий различных органов и организаций ООН

${ }^{25}$ Convention against Discrimination in Education // 429 U.N.T.S. 93. 
по защите детей, а также для усиления направления информационной деятельности ООН и работ по сбору фактов о текущей ситуации в ми$\mathrm{pe}^{26}$. Одним из результатов работы являлись inter alia ежегодные доклады Специального представителя для Комиссии ООН по правам человека, содержащие отчет о предпринятых им действиях для улучшения положения детей в вооруженных конфликтах и их результатах 27 .

В отношении защиты прав ребенка особого внимания заслуживают также акты, принимаемые Комитетом ООН по правам ребенка. В особенности следует выделить так называемые Замечания общего порядка, которые содержат результаты работы Комитета по отдельным аспектам защиты прав ребенка, а также выводы о ситуации в мире по отношению к конкретным правам или группам прав, определяют направления и цели дальнейшей работы Комитета. Примерами таких документов могут служить: Замечание общего порядка № 6 (2005) «Обращение с несопровождаемыми и разлученными детьми за пределами страны их происхождения» ${ }^{28}$, Замечание общего порядка № 7 (2005) «Осуществление прав ребенка в раннем детстве» ${ }^{29}$, Замечание общего порядка № 9 (2006) «Права детей-инвалидов» ${ }^{30}$. Кроме Замечаний общего порядка, Комитет по правам ребенка, рассматривая доклады государств - участников Конвенции, отвечает на них Итоговыми замечаниями и Рекомендациями, которые призваны направлять действия этих государств на улучшение положения детей в стране. Обычно рекомендации Комитета содержат предложения по внесению изменений в национальное законодательство конкретного государства, направленных на повышение степени соответствия положениям Конвенции 1989 года; подчеркивают необходимость создания и поддержания сис-

26 Генеральная Ассамблея ООН. Review of the achievements in the implementation and results of the World Declaration on the Survival, Protection and Development of Children and Plan of Action for Implementing the World Declaration. A/S-27/3.

27 Экономический и социальный совет. Комиссия по правам человека. Права ребенка // Ежегодный доклад Специального представителя Генерального Секретаря по вопросам детей в вооруженных конфликтах, г-на Олара А. Отунну, представленный согласно Резолюции ГА 51/77. E/CN.4/2003/77, 03.03.2003. Оллар А. Оттуну занимал пост Специального представителя Генерального секретаря по вопросу о положении детй в вооруженных конфликтах в период с 1998 по 2005 г. В настоящее время (с апреля 2006 г.) Специальным представителем Генерального секретаря по вопросу о положении детей в вооруженных конфликтах является Радхика Кумарасвами.

${ }^{28} \mathrm{CRC} / \mathrm{GC} / 2005 / 6$.

${ }^{29} \mathrm{CRC} / \mathrm{C} / \mathrm{GC} / 7 / \mathrm{Rev} .1$.

$30 \mathrm{CRC} / \mathrm{C} / \mathrm{GC} / 9$. 
темы постоянного мониторинга и эффективной имплементации положений Конвенции; предлагают учреждение должности омбудсмана по правам ребенка в данном государстве; поддерживают принимаемые государством меры по наиболее полной защите и обеспечению экономических, социальных и культурных прав ребенка в зависимости от актуальных возможностей данного государства. Также одной из рекомендаций Комитета является как можно более широкое распространение среди населения страны данных из предоставленного доклада и замечаний к нему 31 .

Среди других международных организаций, чьи акты рекомендательного характера имеют большое значение для развития и укрепления института защиты прав ребенка, можно назвать Управление Верховного Комиссара ООН по делам беженцев. Исполнительный комитет УВКБ ООН ежегодно на своих заседаниях принимает Заключения по конкретным аспектам проблем беженцев и других категорий вынужденных мигрантов. Среди наиболее важных можно отметить следующие: Заключение № 8 (XXVIII) 1977 года «Определение статуса беженца», которое содержало рекомендации для государств - участников Конвенции о статусе беженцев 1951 года о соответствии процедуры для определения статуса беженца требованиям, изложенным в Заключении; Заключение № 24 (XXXII) 1981 года «Воссоединение семей», содержащее рекомендации, направленные на облегчение воссоединения семей беженцев, а также определение их правового статуса в стране убежища, и многие другие ${ }^{32}$.

Исходя их того, что мы рассматриваем защиту прав ребенка в международном праве как отдельный институт международно-правовой защиты прав человека, к источникам можно причислить также отраслевые принципы защиты прав человека в международном праве. К ним относятся: принцип универсальности, недискриминации, а также принцип неделимости, взаимозависимости и взаимосвязанности прав человека. Все они имеют отражение в приведенных примерах источников анализируемого нами международно-правового института, отсылая к обязанности государств соблюдать все обще-

${ }^{31}$ Kolosov Y. The CRC: Juridical significance and the Committee on the Rights of the Child: Stock taking and new challenges // Understanding Children's Rights / Edited by Eugeen Verhellen. Children's Rights Centre, University of Ghent, Belgium, 1998. P. 411.

32 Иванов Д.В. Беженцы в современном международном праве / Д.В. Иванов. М., 2006. C. 52-53. 
признанные международно-правовые нормы в области прав человека в отношении любых лиц, находящихся под их юрисдикцией, без какой бы то ни было дискриминации, предоставляя им гарантии осуществления присущих им гражданских, политических, экономических и социальных прав ${ }^{33}$.

Существует еще множество достойных внимания актов, являющихся источниками международно-правовой защиты прав ребенка. Сейчас приведем еще раз предложенную нами классификацию источников, регламентирующих международно-правовой институт прав ребенка:

1. Принцип уважения прав человека в международном праве.

2. Универсальные и региональные международно-правовые договоры, предоставляющие защиту прав человека в общем смысле.

3. Универсальные и региональные международно-правовые договоры, гарантирующие защиту прав ребенка.

4. Международно-правовые акты, предоставляющие специальную защиту прав ребенка.

5. Акты рекомендательного характера.

6. Отраслевые принципы международно-правовой защиты прав человека.

Таким образом, мы предложили достаточно аргументированное, на наш взгляд, мнение о том, что международно-правовая защита прав ребенка сформировалась как полноценный самостоятельный институт современного международного права.

33 Международное право / Отв.ред. Ю.М. Колосов, Э.С. Кривчикова. М., 2005. C. $534-535$. 


\section{Modern Theoretical Aspects of the Institute of International Protection and Promotion of the Rights of the Child}

(Summary)

\section{Katazhina Nikonov*}

International protection and promotion of the rights of the child has been evolving from the ancient times. However, the modern phase of its development began in 1945 with the establishment of the Organization of the United Nations. In this article the author shows how the evolution of the international protection of the human rights, especially of the rights of the child, resulted in development of the separate institute of the international protection and promotion of human rights regarded as separate branch of the international law.

In the article you will find the argumentation of the emphasis made on the special protection of the rights of the child, as well as their promotion presented. The author adduces arguments with regard to the common rules and principles of the system of law theory itself, evaluation of the conceptual categories: "human being" and "child", as well as evaluation of the equality of the rights of all humans with respect to special protection of the rights of the child and some limitations of the rights of infants and minors. In the last part of the article the author provides the separate classification of the sources of the institute of international protection and promotion of the rights of the child.

\footnotetext{
* Katazhina Nikonov - post-graduate student of the Chair of International law, MGIMOUniversity MFA Russia.
} 